\title{
Varying forage type, metabolizable protein concentration, and carbohydrate source affects manure excretion, manure ammonia, and nitrogen metabolism of dairy cows
}

\author{
W. P. Weiss, ${ }^{, 1}$ L. B. Willett, ${ }^{*}$ N. R. St-Pierre,† D. C. Borger, ${ }^{*}$ T. R. McKelvey, ${ }^{*}$ and D. J. Wyatt ${ }^{*}$ \\ *Department of Animal Sciences, Ohio Agricultural Research and Development Center, The Ohio State University, Wooster 44691 \\ †Department of Animal Sciences, Ohio Agricultural Research and Development Center, The Ohio State University, Columbus 43210
}

\begin{abstract}
Effects of forage source, concentration of metabolizable protein (MP), and type of carbohydrate on manure excretion by dairy cows and production of ammonia from that manure were evaluated using a central composite experimental design. All diets (dry basis) contained $50 \%$ forage that ranged from 25:75 to 75:25 alfalfa silage:corn silage. Diets contained $10.7 \%$ rumendegradable protein with variable concentrations of undegradable protein so that dietary MP ranged from 8.8 to $12 \%$. Starch concentration ranged from 22 to $30 \%$ with a concomitant decrease in neutral detergent fiber. A total of 15 diets were fed to 36 Holstein cows grouped in 6 blocks. Each block was a replicated $3 \times 3$ Latin square resulting in 108 observations. Manure output (urine and feces) was measured using total collection, and fresh feces and urine were combined into slurries and incubated for $48 \mathrm{~h}$ to measure $\mathrm{NH}_{3}-\mathrm{N}$ production. Feces, urine, and manure output averaged 50.5, 29.5, and $80.1 \mathrm{~kg} / \mathrm{d}$, respectively. Manure output increased with increasing dry matter intake ( $\sim 3.5 \mathrm{~kg}$ of manure/ $\mathrm{kg}$ of dry matter intake), increased concentrations of alfalfa (mostly via changes in urine output), and decreased concentrations of starch (mostly via changes in fecal output). The amount of $\mathrm{NH}_{3}-\mathrm{N}$ produced per gram of manure decreased with increasing alfalfa because excreted $\mathrm{N}$ shifted from urine to feces. Increasing MP increased $\mathrm{NH}_{3}-\mathrm{N}$ produced per gram of manure mainly because of increased urinary $\mathrm{N}$, but increased fecal $\mathrm{N}$ also contributed to the manure $\mathrm{NH}_{3}$. Manure $\mathrm{NH}_{3}-\mathrm{N}$ production per cow (accounts for effects on manure production and $\mathrm{NH}_{3}-\mathrm{N}$ produced per unit of manure) was least and milk protein yields were maximal for diets with high alfalfa ( $75 \%$ of the forage), moderate MP ( $11 \%$ of diet dry matter), and high starch (30\% of diet dry matter).
\end{abstract}

Received March 26, 2009.

Accepted August 3, 2009.

${ }^{1}$ Corresponding author: weiss.6@osu.edu
Key words: dairy cow, manure ammonia, forage, protein

\section{INTRODUCTION}

Manure can be a valuable crop fertilizer, but it also adds to dairy farm costs and can be potentially damaging to the environment. The cost of handling and storing manure is a function of the volume of manure produced; therefore, feeding diets that reduce manure output without adversely affecting milk production should increase profitability by reducing manure-handling costs. A meta-analysis found that replacing corn silage with hay crop forage or increasing the dietary concentrations of NDF or CP were associated with increased manure output by lactating dairy cows (Weiss, 2004), but meta-analyses can be misleading because of the presence of latent variables and hidden confounding between experiments and treatments. Reducing the volume of manure produced has potential economic benefits, but it does not necessarily reduce the environmental risks associated with manure because environmental impact is mostly related to the quantity of specific compounds (e.g., $\mathrm{N}$ and $\mathrm{P}$ ) that are excreted.

Potential effects on air quality are a major reason government regulators are increasingly concerned about excretion of $\mathrm{N}$ via manure (NRC, 2002). Ammonia produced from the activity of naturally occurring enzymes on urea and other $\mathrm{N}$ compounds found in animal manure constitutes a major portion of atmospheric $\mathrm{NH}_{3}$ (NRC, 2002). Most studies have shown that the amount of $\mathrm{NH}_{3}$ produced from cattle manure in the short term (i.e., days) is strongly correlated with the amount of urinary $\mathrm{N}$ in the manure, which is strongly correlated with $\mathrm{N}$ intake (James et al., 1999; Cole et al., 2005). Dietary factors, in addition to the concentration of $\mathrm{CP}$, can affect the amount and route (i.e., fecal or urinary) of $\mathrm{N}$ excretion. The percentage of consumed $\mathrm{N}$ that was excreted via feces decreased and the percentage excreted via urine increased when dairy cows were fed corn silage-based diets compared 
with the percentages when cows were fed alfalfa-based diets (Wattiaux and Karg, 2004). In isonitrogenous diets, replacing byproduct NDF with starch increased urinary $\mathrm{N}$ excretion and reduced fecal excretion of $\mathrm{N}$ (Castillo et al., 2001; Hristov and Ropp, 2003). The shift from urine to fecal excretion of $\mathrm{N}$ as fiber replaces starch could be caused by hindgut fermentation of the fiber (Gressley and Armentano, 2007) or by reduced microbial capture of RDP in the rumen because fiber is usually less fermentable than starch.

Overall intake of $\mathrm{N}$ affects the amount of $\mathrm{N}$ excreted via manure, whereas type of carbohydrate and type of forage have a greater effect on the route (fecal or urinary) of excretion. Both the quantity of $\mathrm{N}$ excreted and the route can affect ammonia production from manure but effects may differ, making interactions between $\mathrm{N}$ intake and other dietary changes likely. To investigate interactions, all factors must be included in an experiment. Therefore, one large experiment was conducted with the objective of determining how common diet modifications (type of forage and concentrations of starch and protein) affected and interacted to affect manure output, amount and route of $\mathrm{N}$ excretion, and short-term ammonia production from manure. Production and digestibility data are reported in a companion paper (Weiss et al., 2009).

\section{MATERIALS AND METHODS}

\section{Treatments and Experimental Design}

The diets were described in detail in a companion paper (Weiss et al., 2009). Briefly, the 3 main effects for this experiment were type of forage, concentration of starch, and concentration of MP. Alfalfa ranged from 25 to $75 \%$ of the forage (the remainder was corn silage), and all diets contained $50 \%$ forage. Starch concentrations were formulated to range from 22 to $30 \%$ (with a concomitant change in NDF concentrations). Using the NRC (2001) model, all diets (DM basis) contained $10.7 \%$ RDP (slight excess based on the model), but the concentration of RUP ranged from 4.1 to $7.1 \%$. This resulted in dietary MP concentrations ranging from 8.8 to $12.0 \%$ MP (\% of DM). The midpoint diet provided $100 \%$ of the MP requirement for $39 \mathrm{~kg} / \mathrm{d}$ of milk (expected yield at the start of the experiment), and the least and greatest MP diets met $85 \%$ and $115 \%$ of the MP requirement. Dietary CP ranged from 14.4 to $17.7 \%$. To meet nutrient specifications, ingredients used in the diets varied. In general, as the proportion of alfalfa increased, the concentration of wheat middling and soybean meal (44\% CP) decreased. To increase MP concentrations, the concentration of nonenzymatically browned soybean meal increased, and as starch increased, the concentration of corn increased, whereas soybean hulls decreased. Diets were formulated to meet or exceed NRC (2001) requirements for minerals and vitamins.

Thirty-six multiparous Holstein cows averaging 128 $(\mathrm{SD}=22)$ DIM were used. The experimental design consisted of 6 blocks (conducted consecutively); each block was an incomplete Latin square with 6 cows and three 21 -d periods resulting in 108 observations. The treatment design was a 3 -factor central composite design with 4 replications of the center point diet $(50 \%$ alfalfa, $26 \%$ starch, and $10.4 \% \mathrm{MP}$ ), resulting in 18 treatments but only 15 diets. The treatment and design structure are described in detail in St-Pierre and Weiss (2009).

After cows were fed treatment diets for $14 \mathrm{~d}$, they were moved to metabolism stalls (identical in size to the freestalls and located within the same barn) and total output of feces, urine, and milk was measured for $4 \mathrm{~d}$ (Weiss et al., 2009). Feeds offered, orts, milk, feces, and urine were weighed and sampled daily and composited over the 4-d collection period. An inline sample splitter diverted approximately $5 \%$ of the urine stream into a vessel containing adequate sulfuric acid $(50 \% \mathrm{vol} / \mathrm{vol})$ to maintain urine $\mathrm{pH}<5$. The remaining urine flowed into a large container without acid. Nitrogen balance was calculated using the weight of all urine, and $\mathrm{N}$ concentration was measured on the acidified urine (corrected for the dilution by the acid).

\section{Sampling and Analyses}

At the conclusion of each collection period, samples of wet feces, acidified urine, and milk were analyzed (in duplicate) for Kjeldahl N (AOAC, 2000) within $24 \mathrm{~h}$. Samples of silages and orts were frozen $\left(-20^{\circ} \mathrm{C}\right)$, lyophilized, ground through a 1-mm screen (Wiley Mill, Arthur H. Thomas, Philadelphia, PA), and analyzed for $\mathrm{N}$ (AOAC, 2000) and DM $\left(100^{\circ} \mathrm{C}\right.$ for $\left.24 \mathrm{~h}\right)$.

\section{Ammonia Emissions}

A solvent evaporator (N-Evap 116, Organomation Assoc. Inc., Berlin, MA) equipped with 10-cm needles was modified by placing a sapphire, $0.03-\mathrm{mm}$ stainless steel flow controller (Part number J-3-SS, O'Keefe Controls Co., Monroe, CT) on the air line leading to each needle (Figure 1). This was necessary to ensure similar air flow to each needle. Air flowed from an air compressor into a 1-L Buchner flask filled with $300 \mathrm{~mL}$ of water (HPLC grade). Air entered the flask via its arm and exited the flask via a tube located approximately $2 \mathrm{~cm}$ above the surface of the water (i.e., the air did not bubble through the water) and then flowed to the manifold on 

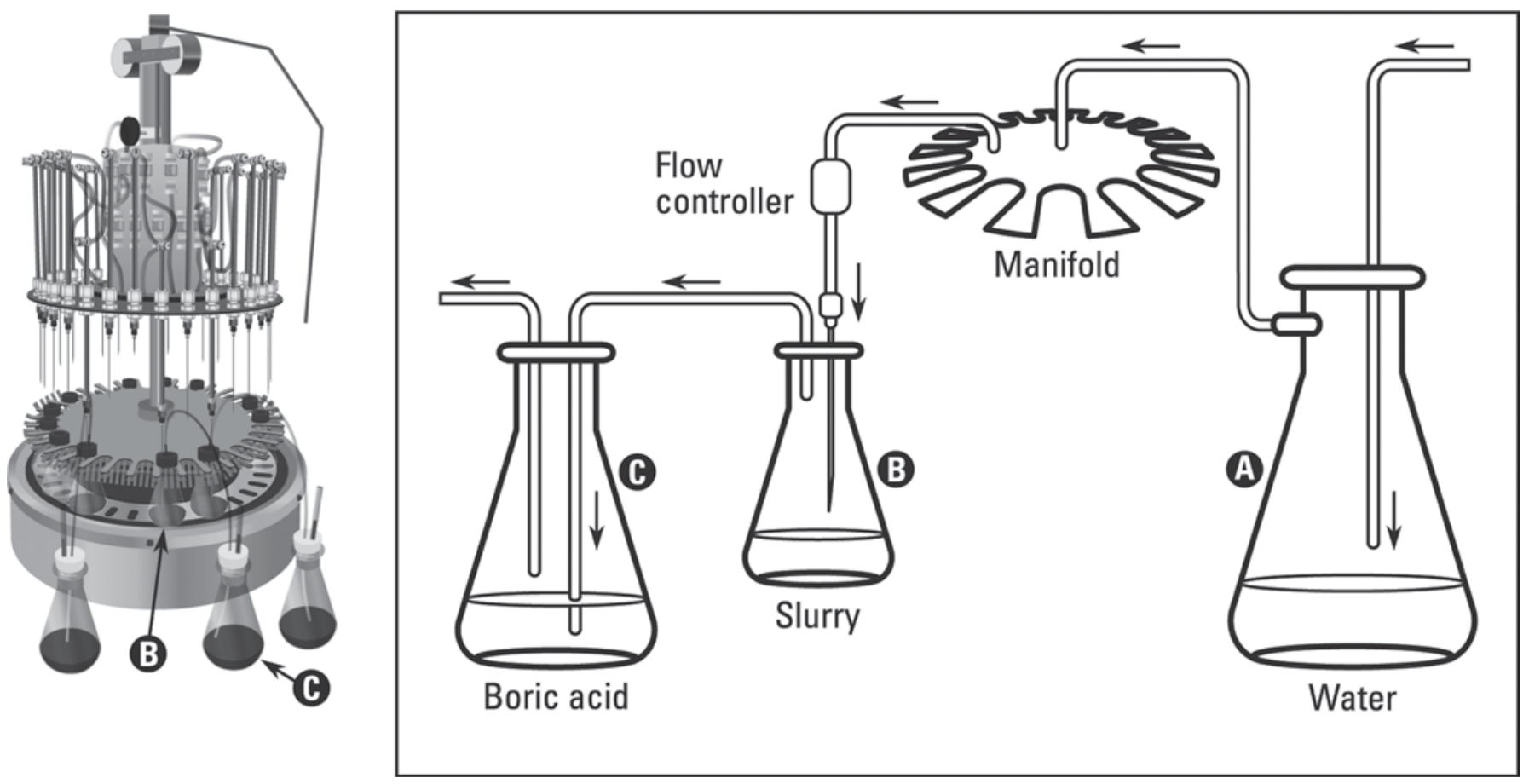

Figure 1. Illustration of the apparatus used to measure $\mathrm{NH}_{3}-\mathrm{N}$ production from manure slurries. Air flowed into a 1-L flask (A) that contained $300 \mathrm{~mL}$ of water to humidify the air and then entered a manifold (drawing on the left) and was distributed to up to 36 flasks (flow rate after the flow controller averaged $14 \mathrm{~mL} / \mathrm{min}$ ). Air entered a $50-\mathrm{mL}$ flask (B) that contained $10 \mathrm{~g}$ of manure slurry (flask in a water bath at $30^{\circ} \mathrm{C}$ ) but was not bubbled through the slurry. Air exited the flask, was bubbled through a boric acid solution (C), and then left the system. Arrows indicate air flow direction. (Illustration by Tim Bowman, Communications and Technology, The Ohio State University.)

the evaporator. Humidifying the inlet air was necessary to prevent the manure slurries from forming a crust. Manure slurries (described in the following) were placed in 50-mL Erlenmeyer flasks that were sealed with a Teflon septum (Tuf-Bond $22 \mathrm{~mm}$, Pierce Biotechnology Inc., Rockford, IL) and a screw-top ring. Flasks were placed into the sample holder on the evaporator, and the needles were inserted through the septums. The tip of each needle was approximately $2 \mathrm{~cm}$ above the manure slurry. A 16-gauge hypodermic needle (with the hub removed) was inserted into a 40-cm long $\times 1$-mm i.d. piece of Teflon tubing. The tubing passed through a \#5 silicone stopper so that $9 \mathrm{~cm}$ of tubing (end without the needle) extended beyond the bottom of the stopper. The stopper also contained a 3-mm i.d. exhaust hole. The 16-gauge needle was inserted into the septum of the manure flask, and the outlet was placed into a 125$\mathrm{mL}$ Erlenmeyer flask containing $100 \mathrm{~mL}$ of $1.2 \%$ (wt/ vol) boric acid solution with a $\mathrm{pH}$ indicator. The entire system, from the flask containing the water through the flasks containing boric acid, was sealed so all air that exhausted the system was bubbled through the boric acid. After the exhaust lines were inserted into all flasks, the sample tray was lowered into a water bath $\left(30^{\circ} \mathrm{C}\right)$ and the system was pressurized. Airflow through each flask was measured during each incubation and averaged $14.3 \mathrm{~mL} / \mathrm{min}$ or about one turnover of air volume every $2.8 \mathrm{~min}$. The flow rate and incubation temperatures were chosen because they could be consistently replicated across runs and were high enough so that manure composition rather than environment was likely the limiting factor for ammonia release.

Two separate ammonia-production experiments were conducted using identical procedures except for the substrate. The first experiment was designed to examine effects of fecal composition on ammonia production. On d 10 of each period, feces were collected per rectum from each cow at approximately $0700 \mathrm{~h}$. Feces $(7 \mathrm{~g})$ were placed into triplicate $50-\mathrm{mL}$ Erlenmeyer flasks, $3 \mathrm{~mL}$ of an artificial urine solution was added, and the flask was immediately sealed with a septum and screw-top ring. The artificial urine solution was 200 $\mathrm{m} M$ sodium bicarbonate and $250 \mathrm{~m} M$ urea in water (HPLC grade) with the $\mathrm{pH}$ adjusted to 8.2. The $\mathrm{pH}$ and sodium bicarbonate concentration was based on Borucki-Castro et al. (2004), and the ratio of feces to urine and the concentration of $\mathrm{N}$ of the artificial urine solution represent the average of numerous digestibility experiments (Weiss, 2004). Flasks were swirled by hand until the mixture was a uniform slurry and placed in 
the evaporator. Two additional slurries were made for each cow for immediate measurement of $\mathrm{pH}$. Boric acid was replaced at $24 \mathrm{~h}$ of incubation, and the experiment ended after $48 \mathrm{~h}$ of incubation.

The second experiment was conducted to measure effects of diet on ammonia synthesis from manure as excreted by a cow. On d 2 of each collection period, samples of feces and urine (not acidified) that were excreted during the preceding 24 -h period were collected from each cow. The ratio of feces to urine was calculated for each cow, and then the appropriate amount of feces from a cow was added to triplicate flasks. After all feces samples were weighed, urine was added so that the ratio of feces to urine was the same as that excreted for each individual cow. The total amount of manure added to each flask was $10 \mathrm{~g}$. After flasks were sealed, they were swirled by hand until the slurry was uniform and placed in the evaporator. Two additional manure slurries were made for immediate measurement of $\mathrm{pH}$. Samples of the wet feces and urine were analyzed for Kjeldahl N. Boric acid was changed at 6, 24, and $48 \mathrm{~h}$ of incubation and immediately titrated. Assuming the slurry had a level surface, the average surface area was $12 \mathrm{~cm}^{2}$ or $1.2 \mathrm{~cm}^{2} / \mathrm{g}$ of manure slurry. Water blanks were used in each run, but the color of the indicator never changed so no corrections were made. In each run, recovery of $\mathrm{N}$ was measured in duplicate flasks containing slurries from a cow fed the control diet. After $48 \mathrm{~h}$, the slurry was digested and analyzed for $\mathrm{N}$ via Kjeldahl, that $\mathrm{N}$ was added to the $\mathrm{N}$ collected in the boric acid flasks over the 48-h incubation, and the sum was compared with the $\mathrm{N}$ added to each flask at time 0 . Recovery averaged $98 \%(\mathrm{SD}=4.2)$.

When the incubations ended at $48 \mathrm{~h}$, sealed flasks containing the slurries were removed from the evaporator, weighed, and placed on ice until being assayed for ammonia (within $4 \mathrm{~h}$ ). A flask was swirled and then opened, and the $\mathrm{pH}$ was measured. A 3-g sample was weighed into a glass distillation tube and immediately distilled into boric acid using a 2200 Kjeltech AutoDistillation unit (Foss Tecator, Hoganas, Sweden), and the boric acid was titrated. Recovery of $\mathrm{NH}_{3}-\mathrm{N}$ from an ammonium sulfate solution was $100 \%$.

\section{Statistical Analyses}

All data were analyzed statistically as described by St-Pierre and Weiss (2009). Briefly, the mixed model included the fixed effects for linear and quadratic main effects and all 2-way interactions. Random effects included block, period within blocks, and cow within blocks.

\section{RESULTS AND DISCUSSION}

\section{Manure Output}

Daily output of manure averaged $80.1 \mathrm{~kg} / \mathrm{d}$ and was composed of approximately $37 \%$ urine and $63 \%$ feces (Tables 1 and 2). Output of all 3 (urine, feces, and manure) were highly variable $(\mathrm{CV}=26.6,16.4$, and 14.9, respectively, data not shown), but much of this variation could be attributed to known factors. Output of feces increased $(P<0.01)$ as DMI increased and concentrations of dietary starch and MP decreased (Table 3). Urinary output increased $(P<0.05)$ with increasing DMI and dietary concentrations of $\mathrm{K}$, alfalfa, and MP (Table 3). Based on prediction errors, the association between DMI and fecal output was much stronger than the relationship between dietary variables and fecal output (Table 3). In contrast, urine output was more closely associated with diet composition than with DMI. Output of manure increased as DMI and dietary concentrations of $\mathrm{K}$ and alfalfa increased but decreased as dietary starch increased. The effects MP had on urine and fecal output were opposite so that MP had no effect on manure output. Manure output was not associated with milk production $(P>0.30$; data not shown).

In our study, manure output increased $3.5 \mathrm{~kg} / \mathrm{kg}$ of DMI compared with $2.6 \mathrm{~kg} / \mathrm{kg}$ of DMI derived from a meta-analysis (Nennich et al., 2005). Milk yield was associated with manure output $(0.6 \mathrm{~kg}$ of manure $/ \mathrm{kg}$ of milk) in that meta-analysis. As would be expected, milk yields and DMI covered a much broader range in the meta-analysis than in this study (milk yields ranged from 2 to 86 vs. 28 to $49 \mathrm{~kg} / \mathrm{d}$, and DMI ranged from 7 to 33 vs. 17 to $30 \mathrm{~kg} / \mathrm{d}$ ). The greater range in the dependent and independent variables would account for some of the difference in results between this study and Nennich et al. (2005). Because Nennich et al. (2005) used a meta-analysis, the DMI and milk yield terms in their equations likely included numerous latent variables or unknown factors (e.g., stage of lactation, BW). These factors were controlled in our experiment and, thus, were not latent components of DMI or milk yield.

The only dietary treatments that affected manure output were starch and alfalfa; no interactions or quadratic effects were observed $(P>0.20)$. As starch increased, manure output decreased linearly $(P<0.01)$, which was caused by reduced fecal output (Table 3 ). On average, cows fed the diet with the least concentration of starch ( $22 \%$ of diet DM) produced about $7 \mathrm{~kg} / \mathrm{d}$ more manure than cows fed the greatest starch diet (30\% of DM). Based on the difference in the starch 
Table 1. Overall means and ranges for manure output and $\mathrm{N}$ utilization by cows fed diets differing in type of forage and concentrations of MP and starch

\begin{tabular}{|c|c|c|c|}
\hline Item & Mean & Minimum & Maximum \\
\hline DMI, kg/d & 24.1 & 16.8 & 29.8 \\
\hline Fecal output, kg/d & 50.5 & 35.6 & 71.3 \\
\hline Urine output, kg/d & 29.5 & 13.8 & 62.6 \\
\hline Manure output, $\mathrm{kg} / \mathrm{d}$ & 80.1 & 55.2 & 110.5 \\
\hline Urine, $\%$ of manure output & 36.7 & 20.5 & 57.8 \\
\hline $\mathrm{N}$ intake, $\mathrm{g} / \mathrm{d}$ & 636 & 438 & 811 \\
\hline Milk N, g/d & 180 & 134 & 223 \\
\hline Apparent $\mathrm{N}$ retention, $\mathrm{g} / \mathrm{d}$ & 32.9 & -40.0 & 118 \\
\hline Urine $N, g / d$ & 187 & 91 & 324 \\
\hline Fecal N, g/d & 236 & 157 & 334 \\
\hline Manure N, g/d & 422 & 289 & 593 \\
\hline Urine $\mathrm{N}, \%$ of manure $\mathrm{N}$ & 44.0 & 25.1 & 56.6 \\
\hline Manure $N, \%$ of $\mathrm{N}$ intake & 66.3 & 54.4 & 76.7 \\
\hline 6 -h volatile $\mathrm{NH}_{3}-\mathrm{N},{ }^{1} \mathrm{~g} / \mathrm{cow}$ per day & 10.4 & 3.7 & 18.2 \\
\hline 24-h volatile $\mathrm{NH}_{3}-\mathrm{N},{ }^{\mathrm{O}} \mathrm{g} / \mathrm{cow}$ per day & 54.3 & 14.3 & 93.8 \\
\hline 48 -h volatile $\mathrm{NH}_{3}-\mathrm{N},{ }^{1} \mathrm{~g} /$ cow per day & 103.4 & 40.5 & 169.5 \\
\hline Total $\mathrm{NH}_{3}-\mathrm{N},{ }^{2} \mathrm{~g} / \mathrm{cow}$ per day & 200.9 & 107.8 & 325.9 \\
\hline
\end{tabular}

${ }^{1}$ Grams of $\mathrm{NH}_{3}-\mathrm{N}$ that were volatilized over 6,24 , or $48 \mathrm{~h}$ per $\mathrm{g}$ of incubated manure multiplied by the daily output of manure from the cow.

${ }^{2}$ Grams of total (volatilized plus amount remaining in the slurry) $\mathrm{NH}_{3}-\mathrm{N}$ produced over $48 \mathrm{~h}$ per g of incubated manure multiplied by the daily output of manure from the cow.

coefficient when DMI was and was not included in the model (Table 3), approximately $30 \%$ of the starch effect was related with a change in DMI and $70 \%$ was a direct effect of starch, most likely caused by increased DM digestibility (Weiss et al., 2009).

As alfalfa replaced corn silage, manure output increased linearly $(P<0.01)$, mainly because of increased output of urine (Table 3). Changing from the diet with the least ( $25 \%$ of total forage) to the greatest alfalfa ( $75 \%$ of total forage) increased manure output by about $10 \mathrm{~kg} / \mathrm{d}$. The alfalfa effect on manure output was partly a direct effect of alfalfa and partly an indirect effect via changes in DMI. When DMI was included in the model to estimate manure output, the alfalfa coefficient was about $50 \%$ less than when DMI was not in the model. Potassium intake has a major effect on urine output (Bannink et al., 1999), and the direct effect of alfalfa on manure and urine output was probably a $\mathrm{K}$ effect. All diets provided adequate K (NRC, 2001). Therefore, supplemental $\mathrm{K}$ was not added to diets, and the change in dietary $\mathrm{K}$ was an expected change as alfalfa replaced corn silage. Alfalfa silage used in this study averaged $3.7 \% \mathrm{~K}$, and the corn silage averaged $1.0 \% \mathrm{~K}$. When dietary $\mathrm{K}$ concentration was included in place of the alfalfa term in the model, predictions errors were very similar for the 2 equations, suggesting that dietary $\mathrm{K}$ concentration accounted for essentially the same variation as did alfalfa (Table 3 ).

Dietary MP did not affect manure output, but it affected output of both feces and urine (Table 3). Increasing MP increased urine output as shown in several other studies (Holter and Urban, 1992; Wattiaux and Karg,
2004; Weiss and Wyatt, 2006). Conversely, increasing MP reduced fecal output. The coefficients for MP in the urine and fecal output models were essentially the same but with opposite signs, resulting in no MP effect on manure output. Dry matter digestibility increased as MP increased because as the concentration of protein in the diet increased, the concentration of NDF decreased, and NDF was less digestible than protein (Weiss et al., 2009). Increasing MP increased urine output because to maintain urine osmolality within a normal range, increased excretion of $\mathrm{N}$ compounds must be accompanied by increased excretion of urinary water (Bannink et al., 1999). Changing from a diet with the greatest concentration of alfalfa $(75 \%$ of the forage) and least concentration of starch (22\%) to a diet with the least concentration of alfalfa $(25 \%)$ and greatest concentration of starch $(30 \%)$ would decrease manure output by $19 \%$ (i.e., from $89 \mathrm{~kg} / \mathrm{d}$ to $72 \mathrm{~kg} / \mathrm{d}$ ).

In our study, the best equation (i.e., lowest error terms) for estimating manure output was the one with only the DMI term. Equations with dietary factors (e.g., alfalfa and starch) had substantially greater error terms. However, in practical, on-farm situations, DMI per cow will not be known.

\section{Nitrogen Excretion}

On average, cows consumed $634 \mathrm{~g}$ of $\mathrm{N} / \mathrm{d}$, and $28 \%$ of that was secreted into milk, $30 \%$ was excreted via urine, $37 \%$ was excreted via feces, and $5 \%$ was apparently retained (Tables 1 and 2). The average $\mathrm{N}$ balance in this study was $33 \mathrm{~g} / \mathrm{d}$, which is equivalent to about 
Table 2. Least squares means for manure output, $\mathrm{N}$ metabolism measures, and ammonia production from manure for cows fed diets with differing concentrations of alfalfa ${ }^{1}(0.25$, $0.323,0.50,0.678$, and 0.75$)$, starch $(22.0,23.2,26.0,28.8$, and $30.0 \%$ of $\mathrm{DM})$, and $\mathrm{MP}(8.8,9.3,10.4,11.5$, and $12.0 \%$ of $\mathrm{DM})$

\begin{tabular}{|c|c|c|c|c|c|c|c|c|c|c|c|c|c|c|c|c|}
\hline \multirow[b]{3}{*}{ Item } & \multirow{3}{*}{$\begin{array}{l}0.25 \\
26.0 \\
10.4\end{array}$} & \multicolumn{4}{|c|}{0.323} & \multicolumn{5}{|c|}{0.50} & \multicolumn{4}{|c|}{0.678} & \multirow{3}{*}{$\begin{array}{c}0.75 \\
26.0 \\
10.4\end{array}$} & \multirow[b]{3}{*}{$\mathrm{SE}$} \\
\hline & & \multicolumn{2}{|c|}{23.2} & \multicolumn{2}{|c|}{28.8} & \multirow{2}{*}{$\begin{array}{l}22.0 \\
10.4\end{array}$} & \multicolumn{3}{|c|}{26.0} & \multirow{2}{*}{$\begin{array}{l}30.0 \\
10.4\end{array}$} & \multicolumn{2}{|c|}{23.2} & \multicolumn{2}{|c|}{28.8} & & \\
\hline & & 9.3 & 11.5 & 9.3 & 11.5 & & 8.8 & 10.4 & 12.0 & & 9.3 & 11.5 & 9.3 & 11.5 & & \\
\hline DMI, kg/d & 22.9 & 23.8 & 24.4 & 23.8 & 23.6 & 25.0 & 23.3 & 24.2 & 23.9 & 24.3 & 24.3 & 25.4 & 24.8 & 23.9 & 24.3 & 0.73 \\
\hline $\mathrm{N}$ intake, $\mathrm{g} / \mathrm{d}$ & 632 & 602 & 703 & 599 & 679 & 650 & 563 & 631 & 668 & 628 & 595 & 721 & 589 & 659 & 655 & 20.9 \\
\hline Feces, kg/d & 49.2 & 50.8 & 49.1 & 51.6 & 48.2 & 56.5 & 48.8 & 51.4 & 49.4 & 47.3 & 53.3 & 51.8 & 53.6 & 41.7 & 49.6 & 2.47 \\
\hline Urine, $\mathrm{kg} / \mathrm{d}$ & 25.4 & 26.5 & 28.6 & 25.3 & 28.1 & 29.5 & 27.8 & 28.3 & 31.5 & 29.3 & 32.9 & 33.5 & 29.9 & 35.3 & 35.4 & 2.72 \\
\hline Manure, $\mathrm{kg} / \mathrm{d}$ & 75.1 & 78.0 & 79.1 & 75.9 & 75.3 & 84.5 & 77.1 & 79.5 & 80.9 & 76.3 & 86.7 & 86.1 & 83.4 & 77.5 & 86.0 & 3.91 \\
\hline Fecal N, g/d & 200 & 209 & 224 & 216 & 236 & 253 & 209 & 238 & 254 & 221 & 248 & 270 & 248 & 230 & 258 & 12.7 \\
\hline Urine $\mathrm{N}, \mathrm{g} / \mathrm{d}$ & 202 & 175 & 239 & 148 & 232 & 180 & 158 & 183 & 199 & 181 & 163 & 214 & 143 & 222 & 189 & 14.4 \\
\hline Manure N, g/d & 400 & 387 & 463 & 367 & 465 & 437 & 365 & 421 & 450 & 406 & 421 & 486 & 392 & 446 & 446 & 18.4 \\
\hline Manure $\mathrm{N}, \%$ of $\mathrm{N}$ intake & 64.1 & 64.8 & 66.5 & 61.0 & 67.9 & 66.5 & 65.3 & 66.6 & 68.1 & 63.9 & 68.5 & 67.7 & 66.0 & 68.4 & 68.0 & 1.83 \\
\hline Vtl. $\mathrm{NH}_{3}-\mathrm{N}^{2}$ & 116 & 101 & 132 & 78 & 134 & 102 & 77 & 100 & 126 & 96 & 86 & 127 & 78 & 110 & 109 & 6.52 \\
\hline Tot. $\mathrm{NH}_{3}-\mathrm{N}^{2}$ & 208 & 195 & 249 & 155 & 255 & 198 & 158 & 196 & 241 & 192 & 172 & 233 & 166 & 210 & 204 & 11.5 \\
\hline
\end{tabular}

${ }^{1}$ Alfalfa is proportion of forage DM (remainder was corn silage).

${ }^{2}$ Grams of volatile (Vtl.) or total (Tot.; Vtl. + amount in slurry) $\mathrm{NH}_{3}-\mathrm{N}$ produced over $48 \mathrm{~h}$ from the daily output of manure from one cow.

Table 3. Effects of dietary treatments, DMI, and dietary K on excretion of manure by dairy cows ${ }^{1}$

\begin{tabular}{|c|c|c|c|c|c|c|c|c|}
\hline \multirow[b]{2}{*}{ Dependent variable } & \multirow[b]{2}{*}{ DMI } & \multirow[b]{2}{*}{ K } & \multirow[b]{2}{*}{ Intercept } & \multirow[b]{2}{*}{ Alfalfa } & \multirow[b]{2}{*}{ MP } & \multirow[b]{2}{*}{ Starch } & \multicolumn{2}{|c|}{ Error $^{2}$} \\
\hline & & & & & & & RMSE & Cow \\
\hline Feces, $\mathrm{kg} / \mathrm{d}$ & $2.54(0.231)$ & -3 & $-10.8(5.69)$ & - & - & - & 3.86 & 3.26 \\
\hline Feces, kg/d & - & - & $81.7(8.74)$ & NS & $-1.40(0.596)$ & $-0.641(0.233)$ & 4.36 & 6.34 \\
\hline Urine, $\mathrm{kg} / \mathrm{d}$ & $1.08(0.321)$ & - & $3.58(7.83)$ & - & - & - & 5.30 & 5.46 \\
\hline Urine, $\mathrm{kg} / \mathrm{d}$ & - & $19.2(3.94)$ & $-2.91(6.78)$ & - & - & - & 4.81 & 5.55 \\
\hline Urine, kg/d & - & - & $7.43(6.67)$ & $17.7(3.65)$ & $1.28(0.604)$ & NS & 4.76 & 5.53 \\
\hline Manure, $\mathrm{kg} / \mathrm{d}$ & $3.54(0.355)$ & - & $-5.61(8.72)$ & - & - & - & 5.00 & 5.78 \\
\hline Manure, $\mathrm{kg} / \mathrm{d}$ & - & $24.6(5.40)$ & $38.5(9.41)$ & - & - & - & 5.88 & 8.82 \\
\hline Manure, $\mathrm{kg} / \mathrm{d}$ & - & - & $92.0(8.86)$ & $20.6(5.01)$ & NS & $-0.855(0.314)$ & 5.71 & 8.85 \\
\hline Manure, $\mathrm{kg} / \mathrm{d}$ & $3.24(0.358)$ & - & $12.3(11.0)$ & $10.8(3.98)$ & NS & $-0.614(0.242)$ & 4.51 & 6.22 \\
\hline Manure, $\mathrm{kg} / \mathrm{d}$ & - & $22.4(5.43)$ & $56.4(14.1)$ & NS & NS & $-0.547(0.320)$ & 5.73 & 8.87 \\
\hline
\end{tabular}

${ }^{1}$ Three analyses were conducted: 1$)$ evaluation of indirect treatment effects [DMI (kg/d) and K (\% of diet DM)]; 2) evaluation of direct treatment effects [alfalfa (proportion of forage DM), MP (\% of diet DM), and starch (\% of DM)]; and 3) evaluation of both direct and indirect effects. For direct dietary treatments, linear, quadratic, and all interactions were tested, but only significant $(P<0.10)$ terms are shown. Values in parentheses are the SE for the coefficient.

${ }^{2} \mathrm{RMSE}=$ root mean square error; Cow $=$ square root of the variance due to cows. When applied to a group, the prediction error $=[\mathrm{RMSE}+($ Cow $/$ square root of $n)]$, where $n=$ number of cows in the group.

${ }^{3} \mathrm{~A}$ dash indicates a term that was not included in the initial analysis. 
$200 \mathrm{~g}$ of protein or approximately $1.3 \mathrm{~kg} / \mathrm{d}$ of body tissue gain (average BW change for all cows on this experiment was $-0.03 \mathrm{~kg} / \mathrm{d}$ ). Cows were in their second or greater lactation and were at least 91 DIM at the start of the experiment. Although an ADG of $1.3 \mathrm{~kg}$ of body tissue is possible, measured $\mathrm{N}$ balance is likely an overestimation of actual tissue retention of N. Inherent errors and biases are included in the measurement of apparent N balance (Spanghero and Kowalski, 1997), but the methodology used in this experiment (e.g., not drying feces before $\mathrm{N}$ analysis, adequate acidification of urine, and 4-d collection periods) should have reduced or eliminated many of those potential errors. Although actual $\mathrm{N}$ retention might be overestimated, there was no evidence of any treatment effects or interactions $(P$ $>0.15)$ on $\mathrm{N}$ retention expressed as grams per day, percent of $\mathrm{N}$ intake, and percent of digestible $\mathrm{N}$ intake (data not shown).

On average, two-thirds of the $\mathrm{N}$ consumed was excreted in manure, and of that, $44 \%$ was in urine and $56 \%$ was in feces. As expected (e.g., Kebreab et al., 2001; Nennich et al., 2005), N intake was the single factor that resulted in the most precise equation for estimating excretion of $\mathrm{N}$ (Table 4). Excretion of manure $\mathrm{N}$ increased $0.76 \mathrm{~g} / \mathrm{g}$ of increased intake of $\mathrm{N}$, which is similar to previous data (Krober et al., 2000; Wattiaux and Karg, 2004; Colmenero and Broderick, 2006). Another equation (Nennich et al., 2005) had a much lower slope (0.53 g of manure $\mathrm{N} / \mathrm{g}$ of increased $\mathrm{N}$ intake), but $\mathrm{BW}$ was included in their equation and BW and DMI should be positively correlated.

All 3 main effects affected $(P<0.02)$ excretion of manure N (Table 4). Increasing starch from the least to the greatest concentration linearly decreased excretion of manure $\mathrm{N}$ by about $30 \mathrm{~g} / \mathrm{d}$ (7.5\% of mean), whereas increasing MP from least to greatest increased manure $\mathrm{N}$ excretion by about $100 \mathrm{~g} / \mathrm{d}$ (24\% of the mean). Both the starch and protein effects were caused mostly by changes in $\mathrm{N}$ intake because when $\mathrm{N}$ intake was included in the model, the starch and protein terms became nonsignificant (Table 4). Increasing alfalfa from least to greatest concentration increased excretion of manure $\mathrm{N}$ by about $30 \mathrm{~g} / \mathrm{d}$. The alfalfa effect was not caused by changes in $\mathrm{N}$ intake because the alfalfa term remained in the model when $\mathrm{N}$ intake was included (Table 4). The increase in manure $\mathrm{N}$ as alfalfa increased was caused by reduced $\mathrm{N}$ digestibility. As expected, $\mathrm{N}$ intake and secretion of milk N increased as MP increased; however, only about $20 \%$ of the increase in $\mathrm{N}$ intake was secreted in milk and $80 \%$ was excreted via manure.

Increasing $\mathrm{N}$ intake had essentially the same marginal effect on excretion of fecal and urinary $\mathrm{N}(\sim 0.4 \mathrm{~g}$ of excreted fecal or urinary $\mathrm{N} / \mathrm{g}$ of increased $\mathrm{N}$ intake;
Table 4). Conversely, several previous studies reported that as $\mathrm{N}$ intake increased, the marginal increase in excretion of urinary $\mathrm{N}$ was much greater than in fecal N (Kauffman and St-Pierre, 2001; Wattiaux and Karg, 2004; Colmenero and Broderick, 2006). In those studies, concentrations of both RDP and RUP were changed to alter $\mathrm{N}$ intake, whereas diets were formulated to be equal in RDP in our study. By definition, RDP is $100 \%$ digestible, and any RDP consumed beyond the rumen microbial $\mathrm{N}$ requirement should be excreted via urine. Because RUP is not $100 \%$ digestible, increasing intake of RUP will increase fecal $\mathrm{N}$ excretion, and because the efficiency of converting digested RUP to milk and body proteins is less than $100 \%$, urinary $\mathrm{N}$ also will increase.

Treatment effects on the amount of $\mathrm{N}$ excreted via manure were mostly mediated via effects on $\mathrm{N}$ intake; however, treatments, independent of $\mathrm{N}$ intake, had substantial effects on the route of $\mathrm{N}$ excretion. Increasing alfalfa increased fecal excretion of $\mathrm{N}$ and decreased urinary $\mathrm{N}$ excretion (Table 4). On average $44 \%$ of the $\mathrm{N}$ excreted was via urine (Table 1), but when the greatest and least alfalfa diets were fed, 41 and $48 \%$, respectively, were excreted via urine. As alfalfa increased, the amount of soybean meal generally decreased (Weiss et al., 2009). In other experiments in which alfalfa silage replaced corn silage and soybean meal, digestibility of $\mathrm{N}$ usually decreased and excretion of fecal $\mathrm{N}$ usually increased (Ruppert et al., 2003; Wattiaux and Karg, 2004; Brito and Broderick, 2006).

Increasing dietary MP linearly increased excretion of both fecal and urinary N (Table 4). The marginal effect on excretion of urinary $\mathrm{N}$ was 3.5 times greater than the marginal effect on excretion of fecal $\mathrm{N}$ (slopes of 26.0 for urinary $\mathrm{N}$ vs. 7.52 for fecal $\mathrm{N}$ ). Based on the regression models for $\mathrm{N}$ intake and excretion of milk, manure, fecal, and urinary $\mathrm{N}$, approximately $17 \%$ of the increased $\mathrm{N}$ intake that occurred as MP increased from the least to the greatest concentrations was secreted in milk, $61 \%$ was excreted via urine, and $22 \%$ via feces. The effect of MP on excretion of total manure $\mathrm{N}$ was essentially an $\mathrm{N}$ intake effect. However, the MP effect on excretion of urinary and fecal $\mathrm{N}$ individually was not only an $\mathrm{N}$ intake effect because the MP term remained in the models when $\mathrm{N}$ intake also was included. If intake of $\mathrm{N}$ was held constant, increasing MP concentration decreased excretion of fecal N. This means that the RUP sources used to increase the MP were more digestible than both microbial protein and the RUP in the low-MP diets. Microbial protein has an estimated true digestibility of $80 \%$, and the RUP in the least MP diet had an estimated (NRC, 2001) true digestibility of $78 \%$. The RUP in the greatest MP diet 
had an estimated true digestibility of $87 \%$. Using the NRC (2001) estimates for RDP, RUP, microbial protein synthesis, and true digestibility of RUP and microbial protein, fecal $\mathrm{N}$ for the greatest MP diet should have been about $20 \mathrm{~g} / \mathrm{d}$ less than for the least MP diet if $\mathrm{N}$ intake was held constant. Based on the regression model, the difference was $25 \mathrm{~g} / \mathrm{d}$. The decrease in fecal $\mathrm{N}$ was countered by a predicted $42 \mathrm{~g} / \mathrm{d}$ increase in excretion of urinary $\mathrm{N}$ (based on the standard error of the coefficients, the changes in fecal and urinary excretion of $\mathrm{N}$ are statistically similar). This is expected because MP by definition is digestible, and if it is not used for tissue or milk protein synthesis, it is excreted via urine.

Feeding the least MP diet (8.8\%) rather than the diet that resulted in maximum milk protein yield $(11.1 \%$ MP) would reduce milk protein yield by $109 \mathrm{~g} / \mathrm{d}$ (Weiss et al., 2009), reduce manure $\mathrm{N}$ excretion by $87 \mathrm{~g} / \mathrm{d}$, and increase the efficiency of converting consumed $\mathrm{N}$ into milk $\mathrm{N}$ from 27 to $30 \%$. The value of milk protein from January 2005 through February 2007 averaged \$6.50/ $\mathrm{kg}$, and MP had an average value during that same time period of $\$ 0.45 / \mathrm{kg}$ (St-Pierre, 2008). Reducing dietary MP from 11.1 to $8.8 \%$ would reduce daily feed costs by about $\$ 0.25 /$ cow (assumed DMI $=24.1 \mathrm{~kg}$, Table 1) but would also reduce daily gross milk income by about $\$ 0.70 /$ cow, resulting in a potential daily lost net income of $\$ 0.45 /$ cow when the least protein diet is fed. This means that the cost of reducing the excretion of $1 \mathrm{~kg}$ of $\mathrm{N}$ into the environment was approximately $\$ 5.17$, which supports the conclusion made by St-Pierre and Thraen (1999) that maximizing N efficiency (milk $\mathrm{N}$ /consumed $\mathrm{N}$ ), if it reduces milk protein yield per cow, can carry a significant economic cost.

\section{Ammonia Production from Feces and Artificial Urine}

This experiment was conducted to determine whether fecal composition affects the production of $\mathrm{NH}_{3}$ from manure. All flasks contained the same amount of wet feces $(7 \mathrm{~g})$ and contained identical quantities of urea $\mathrm{N}$ (21 mg) from the artificial urine solution, but the quantity and chemical form of fecal $\mathrm{N}$ would vary depending on cow and diet. On average, flasks contained $31.9 \mathrm{mg}$ of fecal $\mathrm{N}$, but because the concentration of fecal $\mathrm{N}$ increased linearly $(P<0.01)$ as alfalfa or MP increased, the amount of fecal $\mathrm{N}$ added per flask increased linearly as alfalfa or MP increased. Volatile $\mathrm{NH}_{3}$-N (i.e., $\mathrm{N}$ captured from the exhaust line leaving the flask) and total $\mathrm{NH}_{3}-\mathrm{N}$ (volatile $\mathrm{NH}_{3}-\mathrm{N}$ plus $\mathrm{NH}_{3}-\mathrm{N}$ that remained in the slurry) were measured; however, only total $\mathrm{NH}_{3}$ production will be discussed. The distribution between volatile and slurry $\mathrm{NH}_{3}$ is largely a function of $\mathrm{pH}$, and because artificial urine $\mathrm{pH}$ was held constant, slurry $\mathrm{pH}$ probably did not reflect actual diet effects. 
Table 5. Overall means and ranges for measurements of slurries composed of feces and artificial urine solution $^{1}$

\begin{tabular}{lccc}
\hline Item & Mean & Minimum & Maximum \\
\hline Fecal N, mg/flask & 31.9 & 19.3 & 50.9 \\
Total N, mg/flask & 52.2 & 37.3 & 71.3 \\
Initial slurry pH & 7.28 & 6.75 & 9.14 \\
Slurry pH at 48 h & 9.13 & 8.64 & \\
Volatile $\mathrm{NH}_{3}-\mathrm{N}$ & & & 8.19 \\
at $24 \mathrm{~h}, \mathrm{mg} /$ flask & 6.35 & 2.37 & 14.6 \\
at $48 \mathrm{~h}, \mathrm{mg} /$ flask & 12.1 & 8.61 & 32.1 \\
at $48 \mathrm{~h}, \%$ of N added to flask & 23.5 & 15.2 & 28.1 \\
Total $\mathrm{NH}_{3}-\mathrm{N}$ at $48 \mathrm{~h}, \mathrm{mg} /$ flask & 23.8 & 21.4 & 60.0 \\
Total $\mathrm{NH}_{3}-\mathrm{N}$ at $48 \mathrm{~h}, \%$ of N added & 46.0 & 37.7 & \\
\hline
\end{tabular}

${ }^{1}$ All flasks contained $10 \mathrm{~g}$ of slurry that was composed of $70 \%$ feces from cows fed various diets and $30 \%$ artificial urine $(250 \mathrm{mM}$ urea, $\mathrm{pH} 8.2)$. All incubations ended at $48 \mathrm{~h}$. Total $\mathrm{NH}_{3}-\mathrm{N}=$ volatilized $\mathrm{NH}_{3}-\mathrm{N}+\mathrm{NH}_{3}-\mathrm{N}$ that remained in the slurry.

After $48 \mathrm{~h}$ of incubation, on average, $46 \%$ of the $\mathrm{N}$ added to the flask (equal to $24 \mathrm{mg}$ ) had been converted to $\mathrm{NH}_{3}-\mathrm{N}$, and it was about evenly divided between volatile and slurry-bound phases (Table 5). All flasks contained $21 \mathrm{mg}$ of urea- $\mathrm{N}$ from the artificial urine solution, and the minimum measured total $\mathrm{NH}_{3}-\mathrm{N}$ produced from any flask was $21.4 \mathrm{mg}$. Because of the kinetics of bovine fecal urease (Muck, 1981), all of the urea $\mathrm{N}$ in the slurry was likely hydrolyzed during the 48-h incubation. Assuming all the urea in the artificial urine was converted to $\mathrm{NH}_{3}$, on average, about $3 \mathrm{mg}$ of the $\mathrm{NH}_{3}-\mathrm{N}$ produced was derived from fecal $\mathrm{N}$ (about $9 \%$ of the average fecal $\mathrm{N}$ ). The quantity ( $\mathrm{mg} /$ flask) of $\mathrm{NH}_{3}-\mathrm{N}$ produced increased as MP increased, but no other treatment effects or interactions were observed:

$$
\begin{gathered}
\text { Total } \mathrm{NH}_{3}-\mathrm{N}(\mathrm{mg} / \text { flask })=21.6(1.15)+0.218(0.109) \\
\times \% \mathrm{MP}(\text { root mean square error }=0.932) .
\end{gathered}
$$

Approximately $30 \%$ of the increase in fecal $\mathrm{N}$ added to the flasks as MP increased was converted to $\mathrm{NH}_{3}-\mathrm{N}$ during the 48-h incubation. Increasing alfalfa also increased the amount of fecal $\mathrm{N}$ added to the flask but had no effect on amount of $\mathrm{NH}_{3}-\mathrm{N}$ produced. In the short term (48 h), fecal $\mathrm{N}$ provided by feeding greater concentrations of dietary MP (i.e., increased concentrations of soybean meal) contributed to $\mathrm{NH}_{3}-\mathrm{N}$, whereas, fecal $\mathrm{N}$ from increased alfalfa did not.

\section{Ammonia Production from Manure Slurries}

Manure slurries were constructed from feces and urine that were excreted over a 24 -h period and mixed (within cow) in the same proportion as excreted, but a fixed $10 \mathrm{~g}$ of slurry was added to each flask. Therefore, results in Tables 6 and 7 reflect treatment effects on manure composition, not effects on the mass of manure excreted. The $\mathrm{pH}$ of the slurries averaged 8.05, was not affected by treatment, and was within the range of previous data (Misselbrook et al., 2005). On average, manure was composed of $37 \%$ urine, but $45 \%$ of the manure $\mathrm{N}$ was from urine. The amount of urinary, fecal, and total $\mathrm{N}$ added to each flask increased linearly with increasing MP, but the rate of increase in urinary $\mathrm{N}$ was about 1.5 times greater than the rate of increase in fecal N (data not shown). Increasing alfalfa increased fecal $\mathrm{N}$ per flask, reduced urinary $\mathrm{N}$, and increased total $\mathrm{N}$ per flask. Total $\mathrm{N}$ averaged $52 \mathrm{mg} /$ flask and increased about $13 \mathrm{mg}$ as MP concentrations increased from the least to the greatest concentrations and increased about $2.5 \mathrm{mg} /$ flask as alfalfa increased from least to greatest.

The quantity of $\mathrm{NH}_{3}-\mathrm{N}$ volatilized per flask continued to increase over the incubation period, but the amount volatilized per hour $(0.25 \mathrm{mg} / 10 \mathrm{~g}$ of manure slurry) was the same during the first 6,24 , and $48 \mathrm{~h}$ of incubation (data not shown). Because there were no treatment by incubation time interactions, only $48-\mathrm{h}$ data will be discussed. On average, almost half (48.4\%) of the $\mathrm{N}$ added to flasks was converted into $\mathrm{NH}_{3}-\mathrm{N}$ after $48 \mathrm{~h} ; 52 \%$ was volatile and $48 \%$ remained in the slurry (Table 6 ). The $\mathrm{pH}$ of the slurry following $48 \mathrm{~h}$ of incubation averaged 9.24, which is essentially the pKa of ammonia (i.e., 9.25). At its pKa, $50 \%$ of ammonia is $\mathrm{NH}_{3}$ (volatile) and $50 \%$ is $\mathrm{NH}_{4}^{+}$(nonvolatile). Feeding greater starch diets decreased the $\mathrm{pH}$ of the 48-h slurry, suggesting that some of the fecal starch was being fermented during the incubation. However, the decrease in $\mathrm{pH}$ was quite small (0.05 units as diet starch increased from 22 to $30 \%$ ), which would be expected to decrease the proportion of volatile ammonia from 51 to $48 \%$ of the total ammonia.

The single variable that was the most precise predictor (based on root mean square error) of volatilized and total $\mathrm{NH}_{3}-\mathrm{N}$ was the quantity of total $\mathrm{N}$ added to each flask (Table 7). The amount of volatile and total $\mathrm{NH}_{3}-\mathrm{N}$ produced was positively related to quantity of 
Table 6. Overall means and ranges for slurries made from feces and urine excreted by cows fed various $\operatorname{diets}^{1}$

\begin{tabular}{|c|c|c|c|}
\hline Item & Mean & Minimum & Maximum \\
\hline Fecal N, mg/flask & 28.4 & 17.2 & 48.8 \\
\hline Urine $\mathrm{N}, \mathrm{mg} /$ flask & 23.7 & 10.8 & 39.9 \\
\hline Total N, mg/flask & 52.1 & 33.0 & 67.5 \\
\hline Initial slurry pH & 8.05 & 6.92 & 8.79 \\
\hline Slurry $\mathrm{pH}$ at $48 \mathrm{~h}$ & 9.24 & 8.93 & 9.52 \\
\hline \multicolumn{4}{|l|}{ Volatile $\mathrm{NH}_{3}-\mathrm{N}$} \\
\hline at $6 \mathrm{~h}, \%$ of $\mathrm{N}$ added & 2.5 & 1.1 & 3.9 \\
\hline at $24 \mathrm{~h}, \%$ of $\mathrm{N}$ added & 13.1 & 4.7 & 18.9 \\
\hline at $48 \mathrm{~h}, \%$ of $\mathrm{N}$ added & 24.9 & 13.1 & 34.1 \\
\hline at $48 \mathrm{~h}, \mathrm{mg} / \mathrm{flask}$ & 13.1 & 5.0 & 22.4 \\
\hline Slurry $\mathrm{NH}_{3}-\mathrm{N}$ at $48 \mathrm{~h}, \mathrm{mg} /$ flask & 12.3 & 8.1 & 18.3 \\
\hline Slurry $\mathrm{NH}_{3}-\mathrm{N}$ at $48 \mathrm{~h}, \%$ of $\mathrm{N}$ added & 23.5 & 15.6 & 31.7 \\
\hline Total $\mathrm{NH}_{3}-\mathrm{N}$ at $48 \mathrm{~h}, \mathrm{mg} /$ flask & 25.4 & 13.2 & 38.5 \\
\hline Total $\mathrm{NH}_{3}-\mathrm{N}$ at $48 \mathrm{~h}, \%$ of $\mathrm{N}$ added & 48.4 & 36.3 & 61.4 \\
\hline
\end{tabular}

${ }^{1}$ All flasks contained $10 \mathrm{~g}$ of slurry that was composed of feces and urine in the proportion that was excreted by the cow. All incubations ended at $48 \mathrm{~h}$. Total $\mathrm{NH}_{3}-\mathrm{N}=$ volatilized $\mathrm{NH}_{3}-\mathrm{N}+\mathrm{NH}_{3}-\mathrm{N}$ that remained in the slurry.

urine $\mathrm{N}$ added to flask, but precision was slightly less than for equations with total N (Table 7). The amount of total ammonia produced during the 48-h incubation increased linearly (slope $=0.25, \mathrm{SE}=0.11 ; P<0.05$ ) as the amount of fecal $\mathrm{N}$ added to the flasks increased, but the prediction error (root mean square error = 4.33) was great (data not shown). Based on slopes, an increase of $1 \mathrm{mg}$ of urinary $\mathrm{N}$ increased total $\mathrm{NH}_{3} \mathrm{~N}$ production 3 times more than a 1-mg increase in fecal $\mathrm{N}$ (i.e., $0.74 \mathrm{mg}$ vs. $0.25 \mathrm{mg}$ ). In previous research (James et al., 1999; deBoer et al., 2002; Swensson, 2003; Cole et al., 2005), the amount of urinary $\mathrm{N}$ in a manure slurry usually had a much stronger relationship with ammonia production than did total manure N. Diets in our study were more diverse than in previous studies, and they altered both fecal and urinary $\mathrm{N}$ (sometimes in opposite directions). In the previous studies, diets usually affected urinary $\mathrm{N}$ to a much greater extent than fecal $\mathrm{N}$.

Feeding greater concentrations of alfalfa reduced the amount of volatile and total $\mathrm{NH}_{3}-\mathrm{N}$ produced from the resulting manure (Table 7). Volatile and total $\mathrm{NH}_{3}-\mathrm{N}$ decreased 20 and $24 \%$, respectively, as dietary alfalfa changed from least to greatest concentrations. The decrease of about $7 \mathrm{mg}$ of total $\mathrm{NH}_{3}-\mathrm{N}$ as alfalfa increased from least to greatest corresponds well with the decrease in urinary $\mathrm{N}$ added to each flask (about $6 \mathrm{mg} /$ flask). The most likely reason that increasing dietary alfalfa was associated with less $\mathrm{NH}_{3}-\mathrm{N}$ per unit of manure was that alfalfa shifted $\mathrm{N}$ excretion from urine to feces because $\mathrm{N}$ from alfalfa was less digestible than $\mathrm{N}$ from corn silage and soybean meal. Over the 48-h period, that fecal $\mathrm{N}$ was not a major contributor to $\mathrm{NH}_{3}-\mathrm{N}$ production (as supported by data from the incubations with artificial urine).
Volatile and total $\mathrm{NH}_{3}-\mathrm{N}$ production from manure increased 65 and 55\%, respectively, as MP increased from least to greatest concentrations. As dietary MP increased from least to greatest, the quantity of urinary and total $\mathrm{N}$ increased 8.5 and $12.9 \mathrm{mg} /$ flask, respectively. The increase in total $\mathrm{NH}_{3}-\mathrm{N}$ produced (11 mg/ flask) was greater than the increase in urinary $\mathrm{N}$ but less than the increase in total N. A large proportion of the increase in total $\mathrm{NH}_{3}-\mathrm{N}$ as $\mathrm{MP}$ increased was likely caused by the increase in urinary $\mathrm{N}$, but unlike for alfalfa, a portion of the increase in fecal $\mathrm{N}$ was converted to $\mathrm{NH}_{3}-\mathrm{N}$, again as supported by data from the artificial urine incubations.

The 2 main effects (alfalfa and MP) that influenced $\mathrm{NH}_{3}$ production also affected the amount and route of $\mathrm{N}$ excretion. To determine whether those treatments had effects on $\mathrm{NH}_{3}$ production independent of effects caused by $\mathrm{N}$ excretion, total $\mathrm{N}$ and urinary $\mathrm{N}$ added (mg/flask) were included in the statistical models with volatile and total $\mathrm{NH}_{3}-\mathrm{N}$ as dependent variables (Table 7). Because treatment effects were similar, only total $\mathrm{NH}_{3}-\mathrm{N}$ will be discussed. When total amount of $\mathrm{N}$ added to the flask or amount of urinary $\mathrm{N}$ added to the flask was included in the model, the effects of both MP and alfalfa were statistically significant, which means those treatments would affect total $\mathrm{NH}_{3}-\mathrm{N}$ production, even if the amount of total $\mathrm{N}$ or urinary $\mathrm{N}$ added to each flask was constant. The alfalfa coefficients were -12.7 in the model without the $\mathrm{N}$ added term, -9.74 for the model with total $\mathrm{N}$ added, and -8.17 for the model with urinary $\mathrm{N}$ added. Based on changes in those coefficients, 25 and $36 \%$ of the alfalfa effect on total $\mathrm{NH}_{3}-\mathrm{N}$ production were caused by changes in total $\mathrm{N}$ added or urinary $\mathrm{N}$ added, respectively. A similar comparison of coefficients for the MP term showed that 
approximately $75 \%$ of the MP effect was caused by changes in the quantity of total $\mathrm{N}$ added to the flask. Approximately $40 \%$ of the MP effect was via effects on urinary $\mathrm{N}$ excretion. These model comparisons should not be interpreted to mean that total $\mathrm{N}$ and urinary $\mathrm{N}$ are not major sources of variation in $\mathrm{NH}_{3}$ production. Both were strongly related $(P<0.0001)$ with $\mathrm{NH}_{3-}$ $\mathrm{N}$ production, and the amount of total and urinary $\mathrm{N}$ added were better predictors of $\mathrm{NH}_{3}$ production than were dietary treatments (based on root mean square error). These comparisons do show that within specific dietary modifications (e.g., changes from alfalfa-based diets to corn silage-based diets), a substantial amount of the variation in $\mathrm{NH}_{3}$ production is caused by factors other than changes in the amount of total or urinary $\mathrm{N}$ excreted. Additional research will be needed to identify these factors. Because increasing alfalfa increased the concentration of $\mathrm{N}$ in the manure but decreased the amount of $\mathrm{NH}_{3}-\mathrm{N}$ produced in a 48 - $\mathrm{h}$ period, total $\mathrm{NH}_{3}-$ $\mathrm{N}$ as a percent of total $\mathrm{N}$ added to the flask decreased as alfalfa increased. An increase in excretion of $\mathrm{N}$ does not necessarily increase short-term $\mathrm{NH}_{3}$ production; source of the increase in manure $\mathrm{N}$ must be considered.

\section{Manure Ammonia per Cow}

The assay on which the previous discussion is based used a constant $10 \mathrm{~g}$ of manure for all treatments and, therefore, does not reflect any treatment effects on output of total manure. Ammonia production measurements (over a 48 -h period) were multiplied by the mass of manure produced during the 24 -h period from which urine and feces samples were taken for the assays. On average, the daily output of manure from one cow produced approximately 10,54, and $100 \mathrm{~g}$ of volatile $\mathrm{NH}_{3}-\mathrm{N}$ in 6,24 , and $48 \mathrm{~h}$ (Table 1 ). The average amount of total $\mathrm{NH}_{3}-\mathrm{N}$ (volatile plus slurry) produced over $48 \mathrm{~h}$ from manure excreted by one cow for $1 \mathrm{~d}$ was approximately $200 \mathrm{~g}$ (Tables 1 and 2). Numerous environmental and dietary factors affect the quantity of ammonia produced from manure. We controlled the major environmental factors (e.g., air flow, crust formation, temperature) so that the influence of dietary factors could be measured. Therefore, the absolute quantities of $\mathrm{NH}_{3}-\mathrm{N}$ produced in this experiment might not reflect real farm situations. Ammonia production in this experiment represents the ammonia producing potential of the manure more than it does actual ammonia production.

Treatment effects were essentially constant over time (data not shown), and treatments effects were similar for both volatile and total $\mathrm{NH}_{3}-\mathrm{N}$ production (Table 8). Therefore, only 48 -h total $\mathrm{NH}_{3}-\mathrm{N}$ production will be discussed. Increasing the concentration of alfalfa or

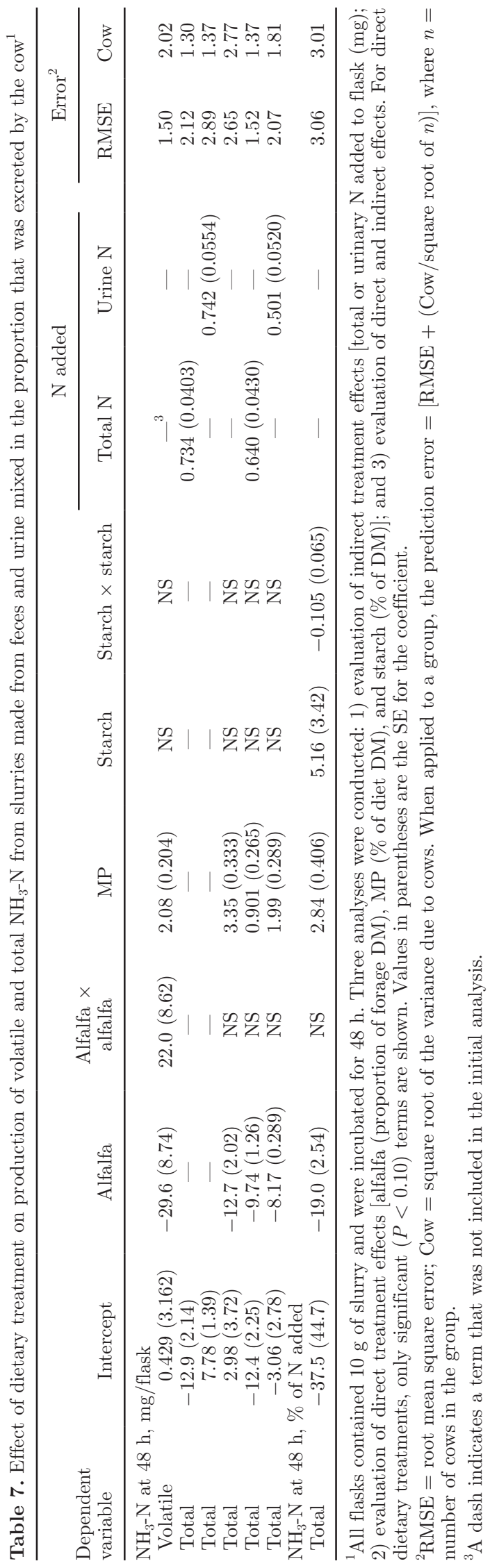

Journal of Dairy Science Vol. 92 No. 11, 2009 
Table 8. Effects of feeding cows diets that differed in concentrations of alfalfa, protein, and starch on the amount of ammonia produced from their manure ${ }^{1}$

\begin{tabular}{|c|c|c|c|c|c|c|}
\hline \multirow[b]{2}{*}{ Dependent variable } & \multirow[b]{2}{*}{ Intercept } & \multirow[b]{2}{*}{ Alfalfa } & \multirow[b]{2}{*}{ MP } & \multirow[b]{2}{*}{ Starch } & \multicolumn{2}{|c|}{ Error $^{2}$} \\
\hline & & & & & RMSE & Cow \\
\hline $\begin{array}{l}\text { Volatile } \mathrm{NH}_{3}-\mathrm{N}^{3} \\
\text { Total } \mathrm{NH}_{3}-\mathrm{N}^{4}\end{array}$ & $\begin{array}{l}-14.5(23.5) \\
-10.9(40.3)\end{array}$ & $\begin{array}{l}-27.9(9.88) \\
-41.6(16.6)\end{array}$ & $\begin{array}{l}17.4(1.58) \\
28.5(2.71)\end{array}$ & $\begin{array}{l}-1.87(0.617) \\
-2.45(1.03)\end{array}$ & $\begin{array}{l}11.5 \\
19.9\end{array}$ & $\begin{array}{l}15.7 \\
24.9\end{array}$ \\
\hline \multicolumn{7}{|c|}{$\begin{array}{l}{ }^{1} \text { Initial analysis included linear and quadratic effects of alfalfa (range of } 0.25 \text { to } 0.75 \text { proportion of forage } \mathrm{DM} \text { ), } \\
\mathrm{MP} \text { (range of } 8.8 \text { to } 12.0 \% \text { of diet } \mathrm{DM} \text { ), and starch (range of } 22 \text { to } 30 \% \text { of } \mathrm{DM} \text { ) and all } 2 \text {-way interactions. } \\
\text { Only significant terms }(P<0.10) \text { are shown. } \\
{ }^{2} \mathrm{RMSE}=\text { root mean square error; Cow }=\text { square root of the variance due to cows. When applied to a group of } \\
\text { cows, the prediction error }=[\mathrm{RMSE}+(\mathrm{Cow} / \text { square root of } n) \text {, where } n=\text { number of cows in the group. } \\
{ }^{3} \mathrm{Grams} \text { of volatile } \mathrm{NH}_{3}-\mathrm{N} \text { produced over } 48 \mathrm{~h} \text { from the manure excreted daily by one cow. } \\
\text { excreted daily by one cow. }\end{array}$} \\
\hline
\end{tabular}

starch in the diet reduced the total quantity of $\mathrm{NH}_{3}-\mathrm{N}$ produced per cow, whereas increasing the concentration of MP increased $\mathrm{NH}_{3}-\mathrm{N}$ production (Table 8). Increasing starch from the least to the greatest concentrations reduced total $\mathrm{NH}_{3}-\mathrm{N}$ production by about $20 \mathrm{~g} /$ cow. In agreement, van der Stelt et al. (2008) reported that increasing NDF concentration (essentially the opposite of increasing starch) increased the production of manure $\mathrm{NH}_{3}-\mathrm{N}$ on a per cow basis. Increasing alfalfa from $25 \%$ of the forage to $75 \%$ of the forage reduced $\mathrm{NH}_{3}-\mathrm{N}$ production by about $20 \mathrm{~g} /$ cow. Increasing MP from 8.8 to $12 \%$ increased $\mathrm{NH}_{3}-\mathrm{N}$ production by $91 \mathrm{~g} / \mathrm{cow}$. Changing from the diet that would produce the greatest amount of $\mathrm{NH}_{3}-\mathrm{N}(25 \%$ of forage as alfalfa, $12 \% \mathrm{MP}$, and $22 \%$ starch) to the diet that produced the least amount of $\mathrm{NH}_{3}-\mathrm{N}$ while maintaining milk protein yield $(75 \%$ alfalfa, $11 \% \mathrm{MP}$, and $30 \%$ starch; Weiss et al., 2009) would reduce $\mathrm{NH}_{3}-\mathrm{N}$ produced from the daily manure output of one cow from 267 to $201 \mathrm{~g}$ (a 25\% decrease). Of that response, $39 \%$ was caused by the change in MP, $31 \%$ by the change in forage, and $30 \%$ by the change in starch. The reduction in $\mathrm{NH}_{3}-\mathrm{N}$ production from manure as dietary starch increased was mostly caused by a reduction in total manure output per cow. The alfalfa effect on manure $\mathrm{NH}_{3}-\mathrm{N}$ was mostly caused by a shift of $\mathrm{N}$ excretion from urine to feces, but the effect of that shift was attenuated because increasing dietary alfalfa resulted in increased manure excretion (Table 3). The reduced production of $\mathrm{NH}_{3}-\mathrm{N} / \mathrm{g}$ of manure as alfalfa concentration increased, however, was greater than the increase in manure excretion. The MP treatment did not affect manure excretion; therefore, increased total $\mathrm{NH}_{3}-\mathrm{N}$ production resulted from more $\mathrm{NH}_{3}-\mathrm{N}$ produced per gram of manure. That was a result of increased concentrations of urinary $\mathrm{N}$ and, to a lesser extent, increased concentration of fecal $\mathrm{N}$.

\section{CONCLUSIONS}

Diet modification substantially affected the excretion of manure by dairy cows. Feeding diets with a high proportion of corn silage and replacing some of the NDF with starch reduced the amount of manure produced without affecting milk production (see Weiss et al., 2009 for production data). Changing from the average diet in this study (50:50 ratio of corn silage to alfalfa and $26 \%$ starch) to a diet with $75: 25$ corn silage:alfalfa and $30 \%$ starch decreased manure output by about $10 \%$. This could result in a significant reduction in manure handling and storage costs. Excretion of $\mathrm{N}$ via manure was mostly a function of $\mathrm{N}$ intake, whereas diet composition affected route (feces or urine) of excretion. Increasing alfalfa with a concomitant decrease in corn silage and soybean meal increased fecal $\mathrm{N}$ but reduced urine N. Increasing MP increased both, but urinary N increased to a greater extent. The amount of $\mathrm{NH}_{3}-\mathrm{N}$ produced from manure was a function of the amount of $\mathrm{N}$ in the manure and the amount of urinary $\mathrm{N}$ in the manure. Increased concentrations of alfalfa reduced $\mathrm{NH}_{3}-\mathrm{N}$ production per unit of manure, whereas it was increased by increasing MP. To reduce $\mathrm{NH}_{3}$ production from manure on a per cow basis, cows should be fed diets with less corn silage and more alfalfa silage; adequate, but not excessive MP; and greater starch concentrations. Changing from the diet that produced the most manure $\mathrm{NH}_{3}-\mathrm{N}$ per cow (25\% alfalfa, $12 \% \mathrm{MP}$, and $22 \%$ starch) to the diet that produced the maximum yield of milk protein ( $75 \%$ alfalfa, $11.1 \% \mathrm{MP}$, and $30 \%$ starch) reduced manure $\mathrm{NH}_{3}-\mathrm{N}$ by $25 \%$ (267 to 201 $\mathrm{g} / \mathrm{cow})$ and increased milk protein yield by $7 \%(1,085$ to $1,166 \mathrm{~g} / \mathrm{d})$.

\section{ACKNOWLEDGMENTS}

Salaries and research support were provided by state and federal funds appropriated to the Ohio Agricultural 
Research and Development Center, The Ohio State University. This project was supported by National Research Initiative Competitive Grant no. 2005-3520615263 from the USDA Cooperative State Research, Education, and Extension. Manuscript 3/09AS.

\section{REFERENCES}

AOAC. 2000. Official Methods of Analysis of AOAC International. Vol. I and II. 17th ed. AOAC Int., Gaithersburg, MD.

Bannink, A., H. Valk, and A. M. VanVuuren. 1999. Intake and excretion of sodium, potassium, and nitrogen and the effects on urine production by lactating dairy cows. J. Dairy Sci. 82:10081018.

Borucki-Castro, S. I., L. E. Phillip, V. Girard, and A. Tremblay. 2004. Altering dietary cation-anion difference in lactating dairy cows to reduce phosphorus excretion to the environment. J. Dairy Sci. 87:1751-1757.

Brito, A. F., and G. A. Broderick. 2006. Effect of varying dietary ratios of alfalfa silage to corn silage on production and nitrogen utilization in lactating dairy cows. J. Dairy Sci. 89:3924-3938.

Castillo, A. R., E. Kebreab, D. E. Beever, J. H. Barbi, J. D. Sutton, H. C. Kirby, and J. France. 2001. The effect of energy supplementation on nitrogen utilization in lactating dairy cows fed grass silage diets. J. Anim. Sci. 79:240-246.

Cole, N. A., R. N. Clark, R. W. Todd, C. R. Richardson, A. Gueye, L. W. Greene, and K. McBride. 2005. Influence of dietary crude protein concentration and source on potential ammonia emissions from beef cattle manure. J. Anim. Sci. 83:722-731.

Colmenero, J. J. O., and G. A. Broderick. 2006. Effect of dietary crude protein concentration on milk production and nitrogen utilization in lactating dairy cows. J. Dairy Sci. 89:1704-1712.

de Boer, I. J. M., M. C. J. Smits, H. Mollenhorst, G. van Duinkerken, and G. J. Monteny. 2002. Prediction of ammonia emission from dairy barns using feed characteristics. Part 1: Relation between feed characteristics and urinary urea concentration. J. Dairy Sci. 85:3382-3388.

Gressley, T. F., and L. E. Armentano. 2007. Effects of low rumendegradable protein or abomasal fructan infusion on diet digestibility and urinary nitrogen excretion in lactating dairy cows. J. Dairy Sci. 90:1340-1353.

Holter, J. B., and J. W. E. Urban. 1992. Water partitioning and intake prediction in dry and lactating Holstein cows. J. Dairy Sci. $75: 1472-1479$

Hristov, A. N., and J. K. Ropp. 2003. Effect of dietary carbohydrate composition and availability on utilization of ruminal ammonia nitrogen for milk protein synthesis in dairy cows. J. Dairy Sci. $86: 2416-2427$.

James, T., D. Meyer, E. Esparza, E. J. DePeters, and H. PerezMonti. 1999. Effects of dietary nitrogen manipulation on ammonia volatilization from manure from Holstein heifers. J. Dairy Sci. 82:2430-2439.

Kauffman, A. J., and N. R. St-Pierre. 2001. The relationship of milk urea nitrogen to urine nitrogen excretion in Holstein and Jersey cows. J. Dairy Sci. 84:2284-2294.
Kebreab, E., J. France, D. E. Beever, and A. R. Castillo. 2001. Nitrogen pollution by dairy cows and its mitigation by dietary manipulation. Nutr. Cycl. Agroecosyst. 60:275-285.

Krober, T. F., D. R. Kulling, H. Menzi, F. Sutter, and M. Kreuzer. 2000. Quantitative effects of feed protein reduction and methionine on nitrogen use by cows and nitrogen emission from slurry. J. Dairy Sci. 83:2941-2951.

Misselbrook, T. H., J. M. Powell, G. A. Broderick, and J. H. Grabber. 2005. Dietary manipulation in dairy cattle: Laboratory experiments to assess the influence on ammonia emissions. J. Dairy Sci. 88:1765-1777.

Muck, R. E. 1981. Urease activity in bovine feces. J. Dairy Sci. 65:2157-2163.

NRC. 2001. Nutrient Requirements of Dairy Cattle. 7th rev. ed. Natl. Acad. Press, Washington, DC.

NRC. 2002. The Scientific Basis for Estimating Air Emissions from Animal Feeding Operations. Natl. Acad. Press, Washington, DC.

Nennich, T. D., J. H. Harrison, L. M. VanWieringen, D. Meyer, A J. Heinrichs, W. P. Weiss, N. R. St-Pierre, R. L. Kincaid, D. L. Davidson, and E. Block. 2005. Prediction of manure and nutrient excretion from dairy cattle. J. Dairy Sci. 88:3721-3733.

Ruppert, L. D., J. K. Drackley, D. R. Bremmer, and J. H. Clark. 2003. Effects of tallow in diets based on corn silage or alfalfa silage on digestion and nutrient use by lactating dairy cows. J. Dairy Sci. $86: 593-609$

Spanghero, M., and Z. M. Kowalski. 1997. Critical analysis of N balance experiments with lactating dairy cows. Livest. Prod. Sci. $52: 113-122$.

St-Pierre, N. R. 2008. Managing measures of feed costs: Benchmarking and economic feed efficiency. Pages 99-112 in Proc. Tri-State Dairy Nutr. Conf., Ft. Wayne, IN. Ohio State University, Columbus.

St-Pierre, N. R., and C. S. Thraen. 1999. Animal grouping strategies, sources of variation, and economic factors affecting nutrient balance on dairy farms. J. Anim. Sci. 77(Suppl. 2):72-83.

St-Pierre, N. R., and W. P. Weiss. 2009. Technical note: Designing and analyzing quantitative factorial experiments. J. Dairy Sci. 92:4581-4588.

Swensson, C. 2003. Relationship between content of crude protein in rations for dairy cows, $\mathrm{N}$ in urine and ammonia release. Livest. Prod. Sci. 84:125-133.

van der Stelt, B., P. C. J. van Vliet, J. W. Reijs, E. J. M. Temminghoff, and W. H. van Riemsdijk. 2008. Effects of dietary protein and energy levels on cow manure excretion and ammonia volatilization. J. Dairy Sci. 91:4811-4821.

Wattiaux, M. A., and K. L. Karg. 2004. Protein level for alfalfa and corn silage-based diets: II. Nitrogen balance and manure characteristics. J. Dairy Sci. 87:3492-3502.

Weiss, W. P. 2004. Factors affecting manure excretion by dairy cows. Pages 11-20 in Cornell Nutr. Conf., Syracuse, NY. Cornell University, Ithaca, NY.

Weiss, W. P., N. R. St-Pierre, and L. B. Willett. 2009. Varying forage type, metabolizable protein concentration, and carbohydrate source affects nutrient digestibility and production by dairy cows. J. Dairy Sci. 92:5595-5606.

Weiss, W. P., and D. J. Wyatt. 2006. Effect of corn silage hybrid and metabolizable protein supply on nitrogen metabolism of lactating dairy cows. J. Dairy Sci. 89:1644-1653. 